\title{
ANALISIS PENERAPAN AKAD PEMBIAYAAN MURABAHAH PADA LEMBAGA KEUANGAN SYARIAH
}

\author{
Rahmi Khoirinnisazzahra Adnina \\ Program Studi Magister Kenotariatan PPS Unisma \\ Jalan Mayjen Haryono Nomor 193 Malang \\ Email: rahmi1694@gmail.com
}

\begin{abstract}
Abstrak
Ada temuan di masyarakat yang dapat dikaji atau dipahami dengan pendekatan norma, bahwa akad murabahah di Bank Muamalat Kota Malang telah ditiadakan sejak tahun 2015 dikarenakan menurut evaluasi dari bank tidak lagi memenuhi prinsip akad murabahah. Nasabah mendatangi pihak supplier atau developer terlebih dahulu, melakukan kesepakatan harga dan membayar uang muka kepada pihak supplier atau developer kemudian mendatangi Bank Muamalat untuk mengajukan permohonan pembiayaan dengan akad murabahah, akan tetapi harga yang disampaikan bukan harga yang sebenarnya namun harga yang sudah dipotong uang muka. Kasus yang sering terjadi adalah kasus yang berkaitan dengan pembiayaan rumah KPR.
\end{abstract}

Kata Kunci: perbankan, pembiayaan, syariah, nasabah, murabahah

\section{Abstract}

There are findings in the society that can be studied or understood using the norm approach, that the murabahah contract at the Muamalat Bank in Malang has been abolished since 2015 because according to the evaluation of the bank it no longer meets the murabahah contract principle. The customer goes to the supplier or developer first, makes a price agreement and pays the advance payments to the supplier or developer then goes to Bank Muamalat to submit a financing request with the murabahah contract, but the price submitted is not the actual price but the price has been deducted by the advance payment. Cases that often occur are cases related to housing mortgages.

Keywords: banking, financing, syariah, customers, murabahah

\section{PENDAHULUAN}

Keberadaan lembaga keuangan di Indonesia merupakan salah satu hal yang penting karena kegiatan usaha bisnis dan ekonomi akan sulit dijalankan tanpa adanya lembaga keuangan. Lembaga keuangan terdiri dari dua jenis, yaitu; lembaga keuangan bank dan lembaga keuangan non-bank. Di Indonesia, salah satu lembaga keuangan yang cukup besar dan sangat memengaruhi aktivitas peningkatan ekonomi adalah lembaga keuangan 
bank/perbankan. Pasal 1 angka 1 Ketentuan Umum Undang-Undang Nomor 10 Tahun 1998 Tentang Perbankan menyebutkan bahwa Perbankan adalah segala sesuatu yang membahas tentang bank, mencakup kelembagaan, kegiatan usaha, serta cara dan proses dalam melaksanakan kegiatan usahanya.

Lembaga keuangan bank di Indonesia telah mengalami perkembangan yang cukup pesat dan signifikan. Secara umum, perbankan yang kita kenal hanya perbankan konvensional, yang dalam pengelolaan siklus keuangannya sangat erat kaitannya dengan persentase bunga atau istilah dalam Islam dikenal dengan riba.Riba adalah suatu tambahan pembayaran dengan persentase tertentu yang disyaratkan terhadap yang berutang atau pembayaran lebih dari utang pokok yang seharusnya karena yang meminjam uang tidak mampu membayar utangnya pada waktu yang ditetapkan.

Bunga atau riba pada bank konvensional sudah menjadi hal umum bagi masyarakat. Persentase bunga dapat diketahui saat masyarakat sebagai nasabah akan melakukan pengajuan pinjaman dana kepada bank atau istilah yang kita kenal sebagai fasilitaskredit. Fasilitas pengajuan kredit yang diajukan atau ditawarkan oleh perbankan konvensional merupakan salah satu solusi masyarakat yang ingin memenuhi kebutuhan ekonominya baik dalam hal investasi maupun konsumtif. Karena pada dasarnya perbankan adalah lembaga intermediary, yaitu lembaga yang menerima dana dari deposan/nasabah dan menyalurkannya kembali kepada nasabah (kreditur) dalam bentuk pelayanan pinjaman dana/pembiayaan.

Adapun pembuatan perjanjian kredit yang dibuat antara bank dan nasabah akan memiliki perbedaan mekanisme yang disebabkan oleh adanya perbedaan persyaratan dan ketentuan serta sistem yang diberlakukan pada masing-masing bank, seperti halnya besar kecilnya jumlah pinjaman yang akan memengaruhi jangka waktu pembayaran dan besarnya bunga yang harus dibayar.

Hingga pada tahun 1992 pemerintah Indonesia memberlakukan istilah syariah pada perbankan dan diterapkannya perbankan syariah. Perbankan syariah adalah segala sesuatu yang menyangkut tentang Bank Syariah dan Unit Usaha Syariah, mencakup kelembagaan, kegiatan usaha, serta cara dan proses dalam melaksanakan kegiatan usahanya. Hadirnya perbankan syariah adalah satu dari sekian upaya pemerintah untuk menunjang peningkatan pada sektor ekonomi yang ditandai dengan meningkatnya kesadaran masyarakat akan nilai-nilai keislaman dalam siklus pengelolaan keuangan di bank konvensional. Masyarakat mulai menyadari imbas dari diterapkan bunga yang harus dibayarkan di luar pinjaman pokok pada perjanjian kredit. 
Pada dasarnya perbankan konvensional dan perbankan syariah memiliki kesamaan dalam segi fungsi, tujuan dan kemanfaatannya, akan tetapi yang menjadi pembeda adalah kegiatan usaha yang dijalankan, pengelolaan siklus keuangan, produk, program dan layanan yang dikeluarkan, sistem kredit yang mana istilah ini digunakan oleh bank konvensional dan/atau pembiayaan, istilah yang digunakan oleh bank syariah kepada nasabah maupun dalam pembuatan perjanjian antara pihak bank dan nasabahnya.

Perbankan syariah menerapkan dan menjalankan kegiatan usahanya merujuk pada hukum Islam, sehingga keberadaan riba atau bunga ini merupakan suatu hal yang dilarang, tidak sedikit dari beberapa kalangan masyarakat menganggap bahwa dengan keberadaan bank syariah di Indonesia umat muslim dapat mulai meninggalkan atau tidak lagi menggunakan jasa bank konvensional dalam melakukan kegiatan yang berhubungan dengan pengelolaan siklus keuangan terlebih dalam hal pengajuan pinjaman atau kredit.

Produk layanan yang dijalankan oleh bank berplat syariah salah satunya adalah pembiayaan. Pembiayaan merupakan kegiatan penyaluran dana kepada masyarakat sebagai nasabah sesuai dengan prinsip syariah. Pembiayaan pada perbankan syariah memiliki beberapa macam produk yang salah satunya adalah pembiayaan dengan akad murabahah. Murabahah merupakan kegiatan jual beli antara bank dan nasabah sebagai pembeli dengan harga asli yang ditambah margin keuntungan dan akan dibayar oleh nasabah secara berangsur sesuai dengan jangka waktu yang ditentukan.

Untuk mengetahui kebenarannya maka penulis akan membahas penerapan produk pembiayaan dan pengelolaan serta penyaluran dana kepada masyarakat sebagai nasabah yang berkaitan dengan akad murabahah di dalam perjanjian pembiayaan.

\section{METODE PENELITIAN}

Untuk mengkaji pokok permasalahan, metode penelitian hukum yang digunakan dalam penelitian lapangan ini,yaitu yuridis empiris (field research). Untuk itu, yang menjadi fokus dan sentral penelitian ini adalah melihat hukum dalam arti yang nyata, meneliti efektivitas sistem kerjanya hukum di masyarakat. Pendekatan dalam penelitian lapangan ini adalah pendekatan sosio-legal (socio-legal approach) yang menggunakan berbagai disiplin ilmu sosial dan hukum untuk mengkaji keberadaan hukum positif (negara) sehingga mampu memberikan pandangan yang lebih holistis atas fenomena hukum di masyarakat. ${ }^{1}$ Penelitian ini bertujuan untuk

1 Jonaedi Efendi dan Johnny Ibrahim, Metode Penelitian Hukum Normatif dan Empiris, (Depok : Prenadamedia Group, 2018), hal, 149-150. 
mendeskripsikan fakta yang sesuai dengan fenomena yang terjadi secara rinci. Penelitian ini juga menggunakan pendekatan kualitatif.

Penelitian yang bersifat yuridis empiris ini dilakukan dengan menggunakan jenis dan sumber data dari data primer, data sekunder dan data tersier. ${ }^{2}$ Teknik pengumpulan data yang digunakan adalah dengan wawancara dan dokumentasi serta menggunakan teknik analisa data dengan penelitian deskriptif-kualitatif.

\section{PEMBAHASAN}

Dapat dipahami lebih awal, bahwa produk dan layanan yang dikeluarkan dan dijalankan oleh bank Muamalat terbagi menjadi 2 bagian, pertama, produk serta layanan yang diperuntukkan bagi consumer and retail banking di mana cakupannya lebih luas karena terkait dengan pangsa pasar yang lebih ramai membuat kalangan perbankan sangat tertarik untuk mengeluarkan layanan tersebut; ${ }^{3}$

Kedua, diperuntukkan bagi corporate banking, yaitu pelayanan perbankan kepada perusahan besar dan unit usaha bukan eceran yang memiliki struktur keuangan yang kuat. ${ }^{4}$

Bank Muamalat Indonesia juga mengeluarkan produk dan layanan untuk nasabah dalam bentuk Pembiayaan consumer and retail banking, adapun bentuknya terbagi menjadi 3 (tiga) macam, yaitu berikut:

a. KPR IB Muamalat

b. Pembiayaan IB Muamalat Pensiun.

c. Pembiayaan IB Multiguna

Selanjutnya, berikut ini akan dijabarkan beberapa produk dan layanan Bank Muamalat (Kota Malang) terkait dengan corporate banking atau hubungan nasabah dengan Bank Muamalat dalam hal ini badan hukum Indonesia, yaitu :

Tabel 1

Produk dan Layanan Corporate Banking

\begin{tabular}{|c|c|c|c|c|c|}
\hline \multicolumn{6}{|c|}{ Corporate Banking } \\
\hline Tabungan & Giro & Deposito & $\begin{array}{c}\text { Internasional } \\
\text { Banking }\end{array}$ & $\begin{array}{c}\text { Trade } \\
\text { Fiannac }\end{array}$ & $\begin{array}{l}\text { Layananan } \\
\text { Corporate }\end{array}$ \\
\hline $\begin{array}{l}\text { Tabungan } \\
\text { Muamalat } \\
\text { Mudharaba }\end{array}$ & $\begin{array}{c}\text { Giro IB } \\
\text { Hijrah } \\
\text { Ultima }\end{array}$ & $\begin{array}{l}\text { Deposito } \\
\text { IB Hijrah } \\
\text { Mudhara- }\end{array}$ & $\begin{array}{c}\text { Bank } \\
\text { Muamalat } \\
\text { Indonesia - }\end{array}$ & $\begin{array}{c}\text { Bank } \\
\text { Garansi }\end{array}$ & $\begin{array}{l}\text { Layanan } \\
\text { Muamalat } \\
\text { Cash }\end{array}$ \\
\hline
\end{tabular}

${ }^{2}$ Ibid

${ }^{3}$ Cecep Supriadi, 2014, Bagaimana Masa Depan Retail Banking di Indonesia? diakses dari https://marketing.co.id/ pada 24 Juli 2019.

${ }^{4}$ Kamus Bisnis dan Bank diakses di http://www.mediabpr.com/ pada 24 Juli 2019. 


\begin{tabular}{|c|c|c|c|c|c|}
\hline $\begin{array}{c}\mathrm{h} \\
\text { Corporate } \\
\text { IB } \\
\end{array}$ & Corporate & bah & $\begin{array}{c}\text { National } \\
\text { Commercial } \\
\text { Bank }\end{array}$ & & $\begin{array}{c}\text { Manageme } \\
\mathrm{nt}\end{array}$ \\
\hline --- & $\begin{array}{c}\text { Giro IB } \\
\text { Muamalat } \\
\text { Attijary } \\
\text { Corporate }\end{array}$ & --- & $\begin{array}{c}\text { Bank } \\
\text { Muamalat } \\
\text { Indonesia - } \\
\text { Bank } \\
\text { Muamalat } \\
\text { Malaysia } \\
\text { Berhad }\end{array}$ & $\begin{array}{c}\text { Trade } \\
\text { Finance } \\
\text { - Ekspor }\end{array}$ & $\begin{array}{c}\text { Jasa } \\
\text { Layanan } \\
\text { ESCROW }\end{array}$ \\
\hline --- & --- & --- & $\begin{array}{c}\text { Bank } \\
\text { Muamalat } \\
\text { Indonesia - } \\
\text { MayBank } \\
\end{array}$ & $\begin{array}{c}\text { Trade } \\
\text { Finance } \\
\text { - Impor }\end{array}$ & $\begin{array}{c}\text { Layanan } \\
\text { Cash Pick- } \\
\text { Up and } \\
\text { Delivery }\end{array}$ \\
\hline --- & --- & --- & $\begin{array}{c}\text { Remittance IB } \\
\text { Muamalat }\end{array}$ & $\begin{array}{c}\text { SBLC } \\
\text { (Standby } \\
L / C)\end{array}$ & --- \\
\hline
\end{tabular}

Sumber: Data sekunder yang telah diolah

Produk pembiayaan yang diperuntukkan bagi corporate banking, terbagi atas 4 (empat) jenis pembiayaan yang akan penulis jabarkan sebagi berikut :

a. IB Muamalat Asset Refinance Syariah;

b. IB Muamalat Modal Kerja;

c. IB Muamalat Investasi;

d. IB Muamalat Hunian Syariah Bisnis.

\section{Penerapan Akad Pembiayaan Murabahah}

Kesadaran masyarakat mulai muncul dan meningkat signifikan akan kebutuhan suatu lembaga keuangan yang menjalankan kegiatan lalu lintas keuangannya berdasarkan prinsip syariah atau hukum Islam. Sehingga dengan hadirnya perbankan syariah di Indonesia merupakan inovasi yang cukup besar dan dapat membantu masyarakat lebih tenang dalam melakukan hal-hal yang bersangkutan dengan kebutuhan mereka seperti salah satunya kebutuhan pembiayaan.

Pembiayaan adalah istilah yang digunakan pada perbankan syariah sementara pada bank konvensional menggunakan istilah kredit. Lalu lintas perkreditan merupakan hal yang paling riskan jika berbicara terkait bunga/riba. Untuk itu perbankan syariah menggunakan istilah pembiayaan dan mengeluarkan salah satu produknya yakni pembiayaan-pembiayaan yang dapat dilakukan dengan akad murabahah. 
Pembiayaan dengan akad murabahah adalah akad yang cukup mudah dan aman karena dapat terhindar dari bunga/riba yang dikhawatirkan oleh masyarakat. Akad murabahah adalah akad jual beli antara penjual dalam hal ini Bank Syariah dan pembeli dalam hal ini nasabah terhadap barang yang telah pesan dengan harga pokok yang ditambah dengan margin keuntungan sesuai yang disepakati oleh kedua pihak. Dalam hal ini bank berplat syariah sebagai penjual membeli dari pihak ketiga yaitu Developer atau Supplier dan harus benar-benar memiliki barang yang menjadi objek jual beli tersebut kemudian menjualnya kepada nasabah sebagai pembeli dengan keuntungan yang telah disebutkan tadi.

Secara umum proses pembiayaan dengan akad murabahah dimulai dari peruntukkannya, pengajuan permohonan kepada Bank Syariah, proses analisis hingga tejadi kesepakatan antara kedua belah pihak. Penggunaan akad murabahah, biasa dilakukan untuk pengajuan pembiayaan dalam bentuk investasi dan konsumtif. Hal-hal yang termasuk pembiayaan investasi, karena nasabah ingin menginvestasikan suatu barang dengan bantuan dari bank atau akan ada barang yang diinginkan nasabah untuk menjadi objek investasi. Berbeda dengan pembiayaan konsumtif, biasanya barang yang akandibeli oleh nasabah sudah jelas dan terukur menurut penilaian bank syariah. Barang/benda yang yang termasuk dan diperbolehkan menjadi objek jual beli dengan Akad murabahah harus memenuhi syarat pembelian asset yang tidak bertentangan dengan syariah Islam dalam bentuk barang bergerak maupun barang tidak bergerak, yaitu seperti, tempat tinggal, kendaraan bermotor (alat transportasi), alat-alat industri, pabrik, gudang dan asset tetap lainnya.

Untuk pembelian barang yang diinginkan oleh nasabah sebagai calon pembeli, pihak bank syariah memiliki hak untuk menentukan dan memilih supplier yang dipercaya oleh bank. Supplier adalah orang atau badan hukum sebagai penyedia barang yang diinginkan oleh nasabah dan akan dibeli oleh bank syariah, lalu dijual kepada nasabah bersamaan dengan pembuatan akad perjanjian. Namun, pada kondisi tertentu, bank syariah dapat membuat perjanjian tambahan berupa akad wakalah (perjanjian perwakilan) agar nasabah dapat membeli barang berdasarkan spesifikasi yang terteradi dalam akad. Adapun berkas mengenai Purchase Order (PO) atas pembelian barang, pihak yang menerbitkan dan melakukan pembayaran adalah Bank Syariah kepada supplier.

Bila nasabah ingin memilih supplier yang berbeda, maka bank berplat syariah memiliki hak untuk menilai supplier tersebut guna melihat kelayakannya sesuai dengan karakteristik yang telah ditetapkan oleh bank syariah. Sudah tentu kriteria mutlak yang harus melekat pada nasabah bahwa nasabah sebagai pembeli memenuhi syarat wajib seperti cakap 
hukum, sehingga dapat melakukan dan menjalankan transaksi serta memiliki keinginan dalam melakukan pemabayaran untuk menghindari adanya wanprestasi.

Harga jual beli dari obyek perjanjian merupakan harga yang disepakati antara pihak bank berplat syariah sebagai penjual dan nasabah sebagai pembeli, yang mana ditetapkan sesuai akad murabahah dan tidak diperkenankan ada perubahan selama pelaksanaan perjanjian.

Jangka waktu yang diberikan oeleh Bank Muamalat Kota Malang dapat diberikan dalam jangka waktu minimal 1 tahun, 5 tahun dan waktu maksimal 10-15 tahun, berdasarkan kemampuan nasabah untuk membayar angsuran dan besar kecilnya pembiayaan yang diberikan oleh bank. Ketentuan terkait waktu tidak boleh berubah, namun jika ada perubahan maka harus ada kesepakatan antara bank syariah dan nasabah.

Terakhir untuk ketentuan lainnya, seperti denda atas tunggakan nasabah, denda di dalam akad pembiayaan syariah sebenarnya tidak diperkenankan bahkan termasuk dalam dana riba yang diharamkan dalam prinsip syariah yang merujuk pada hukum Islam. Akan tetapi pada pelaksanaannya dan diatur oleh regulasi perbankan syariah diberlakukan dengan maksud untuk mengikat nasabah agar teratur untuk membayar angsuran atas piutang murabahah.

Pengajuan permohonan pembiayaan kepada bank-bank syariah maupun konvensional tidak akan terlepas dari prosedur dan syarat-syarat yang harus ditempuh dan dipenuhi. Syarat-syarat yang dibutuhkan dan prosedur yang harus ditempuh oleh nasabah sebenarnya hampir sama dengan yang ditetapkan oleh bank konvensional. Syarat dan ketentuan umum pembiayaan murabahah, yaitu:

1. Perorangan maupun Badan Hukum;

2. Cakap hukum;

3. Memenuhi prinsip $5 \mathrm{C}$, yaitu:

a. Character (watak);

b. Collateral (jaminan);

c. Capital (modal);

d. Condition of Economy (prospek usaha);

e. Capability (kemampuan);

4. Memenuhi ketentuan dari bank Indonesia dan regulasi pemerintah, berdasarkan Undang-Undang No. 10 Tahun 1998 tentang Perubahan Undang-Undang Nomor 7 Tahun 1992 tentang Perbankan; dan

5. Adanya dhomman (agunan)

Jika bank sudah menjalankan analisis pembiayaan, bank akanmerasa yakin dan percaya bahwa pembiayaan yang akan dibiayai layak (fesible). Berikut ini merupakan penjabaran dari prinsip 5C yang dilakukan oleh bank 
terhadap pengajuan pembiayaan khususnya murabahah sebagaimana berikut:

\section{a. Character}

Tahap yang dilakukan untuk menganalisis karakter dan watak dari masyarakat yang ingin diberikan pembiayaan.Hal ini perlu dilaksanakan oleh bank dapat mengetahui bahwa masyarakat sebagai calon debitur benarbenar berkeinginan melaksanakan kewajibannya untuk mengembalikan pembiayaan hingga pelunasan sesuai dengan jangka waktu yang telah diperjanjikan.Dari analisis ini juga bank dapat mengetahui bahwa calon nasabah memiliki karakter yang baik, jujur dan berkomitmen terhadap pembayaran kembali pembiayaan.

Adapun tahap-tahap lanjutan yang perlu dilakukan oleh bank agar mengetahui character calon nasabah, yaitu:

\section{1) BI Cheking}

Bank dapat melakukan analisis dengan meneliti melalui $B I$ Checking, yakni melakukan pengecekkan langsung secara online mengenai data calon nasabah yang terhubung dengan Bank Indonesia serta mengetahui dengan jelas bahwa calon nasabah memiliki kredibilitas yang baik dalam hal pembiayaan bila pernah menjadi debitur pada bank lainnya.

\section{2) Informasi dari Pihak Lain}

Jika masyarakat yang diberikan pembiayaan belum pernah memiliki atau mengajukan pinjaman pada bank lain, bank dapat meneliti calon nasabah dengan mencari informasi dari pihak-pihak lain yang mengenal dengan baik calon nasabah. Bank dapat mencari informasi tentang calon nasabah melaui tempat tinggalnya atau tempat calon nasabah bekerja serta rekan usahanya. Informasi dari pihak lain tentang calon nasabah, akan lebih meyakinkan bagi bank untuk mengetahui character calon nasabah.

\section{b. Capacity}

Merupakan penilaian terhadap kemampuan masyarakat sebagai nasabah saat mengatur usahanya agar memperoleh laba. Dari laba yang diperoleh maka nasabah dapat dipercaya untuk membayar sesuai dengan jangka waktu pembayaran yang telah disepakati setelah bank syariah menyetujui pembiayaan. Analisis ini sangat penting dilakukan karena berhubungan dengan faktor internal perusahaan dan merupakan faktor utama agar bisa membayar apabila keuangan calon debitur dalam kondisi yang baik, maka kualitas pembayaran pembiayaannya juga tidak perlu dikhawatirkan.

Adapun contoh dari capacity ialah suatu badan hukum yang akan diteliti perputaran keuangannya dari tahun ke tahun apakah mengalami peningkatan atau penurunan. 
Berikut ini merupakan macam-macam cara yang dapat dijalankan bank syariah untuk mengetahui kesanggupan keuangan calon debitur, yaitu: 1) Melihat Laporan Keuangan

Dengan melihat informasi pembukuan keuangan dari calon debitur, bank syariah bisa mengetahui sumber dana yang diperoleh serta keseluruhan laporan arus keluar masuk dana (kas), sehingga akan terlihat perputaran keuangan dengan jelas dari calon nasabah antara perputaran uang yang masuk dengan uang yang keluar atau penggunaan dananya.

2) Memeriksa slip gaji dan rekening tabungan

Bila calon debitur yang mengajukan pembiayaan adalah seorang karyawan, bank bernama syariah dapat meminta fotokopi slip gaji untuk waktu 3 bulan terakhir dan didukung oleh rekening tabungan minimal untuk waktu 3 bulan terakhir. Dengan melihat dan meneliti slip gaji serta rekening tabungan, bank syariah dapat mengetahui uang yang didapatkan dan uang yang dikeluarkan calon debitur. Berkas keuangan tersebut merupakan analisis dasar tentang perputaran keuangan calon debiturjika pembiayaan yang diajukan telah disetujui oleh bank syariah.

3) Survei ke lokasi usaha calon nasabah

Survei yang dilakukan oleh pihak bank syariah diperbolehkan agar mengetahui usaha calon debitur dengan melakukan pengamatan secara langsung.

c. Capital

Analisis capital merupakan analisis modal yang dimiliki oleh calon nasabah.Bertujuan untuk mengukur kemampuan usaha pemohon untuk mendukung pembiayaan dengan modalnya sendiri (own share). Semakin besar kemampuan modalnya berarti semakin besar porsi proyek usaha didukung oleh modal sendiri atau sebaliknya. ${ }^{5}$

Jika calon debitur yang mengajukan pembiayaan merupakan suatu badan hukum atau perusahaan, maka penilaian pada susunan modal ini sangat penting untuk menilai tingkat debt to equity ratio. Suatu badan hukum dianggap kuat jika dapat menyelesaikan berbagai macam risiko jika jumlah modal sendiri yang dimiliki cukup besar.Analisis perputaran keuangan dapat dilakukan oleh bank syariah agar mengetahui jumlah modal perusahaan.

d. Collateral

Disebut juga sebagai jaminan, yaitu sebagaii sumber pembayaran kedua yang diberikan oleh calon nasabah atas pembiayaan yang diajukan. Dalam hal dikemudian hari nasabah tidak dapat membayar angsurannya selama kurun waktu 3 (tiga) bulan berturut-turut, maka nasabah dianggap

${ }^{5}$ Ahmad Ifham Sholihin, 2010, Buku Pintar Ekonomi Syariah, Jakarta : Gramedia 
telah melakukan wanprestasi dan bank syariah sudah memiliki hak untuk mengeksekusi dan menjual jaminan dengan cara melalui pelelangan. Kemudian uang dari hasil pelelangan untuk melunasi pembiayaan.

e. Condition of Economy

Bank perlu mempertimbangkan dan melakukan analisis akibatakibat yang dapat mempengaruhi bidang usaha calon debitur terkait dengan kondisi perekonomian dimasa yang akan datang.

Berikut ini merupakan hal-hal yang dapat dianalisis dengan condition of economy yaitu:

1) Kebijakan pemerintah.

2) Bank syariah tidak terlalu fokus terhadap analisis condition of economy pada pembiayaan konsumtif.

Terkait dengan prinsip 5C, setiap calon nasabah yang mengajukan permohonan pembiayaan kepada bank yang menggunakan nama "syariah", akan dianalisis secara menyeluruh dan rinci, sehingga hasil analisis akan menunjukkan layak tidaknya pengajuan pembiayaan calon debitur. Analisis yang perlu dilakukan secara teliti karena merupakan informasi dasar agar bank memiliki keyakinan penuh dan percaya kepada calon debitur yang ingin diberikan pembiayaan. Namun pada praktiknya, bank akan lebih focus pada 3 prinsip utama yakni, character, capacity, dan collateral. Berdasarkan 3 point prinsip dasar pemberian pembiayaan tersebut merupakan faktor penting yang tidak dapat ditinggalkan sebelum mengambil keputusan.

Tujuan bank dalam melakukan analisis pembiayaan agar bank dapat mencegah secara dini kemungkinan terjadinya kelalaian pembayaran oleh nasabah. Analisis pembiayaan yang baik dan tepat akan menjadi salah satu faktor dan acuan yang memiliki pengaruh besar bagi bank berlabel syariah terkhusus Bank Muamalat saat mengambil keputusan untuk menyetujui/menolak permohonan pembiayaan.

Pembiayaan murabahah adalah pembiayaan yang cukup mudah dan sudah sangat umum dilakukan di dunia perbankan syariah dengan nasabahnya yang nantinya akan tertuang dalam perjanjian jual beli. Akan tetapi seiring berkembangnya zaman dan berjalannya waktu, ada beberapa hal yang dapat dikatakan tidak relevan lagi untuk dilakukan.

Fatwa DSN MUI tentang akad murabahah, bahwa perbankan syariah harus melaksanakan kegiatan usaha dan pelayanannya sesuai dengan prinsip syariah atau hukum Islam, seperti yang tertuang pada Peraturan Bank Indonesia tentang Pengelolaan Dan Penyaluran Dana Berupa Pembiayaan Syariah Kepada Nasabah bahwa perbankan syariah dapat menjalankan kegiatan usaha syariah salah satunya adalah pembiayaan dengan akad murabahah. 
Berbeda halnya dengan Bank Muamalat Cabang Utama Kota Malang yang sebelumnya telah menjalankan kegiatan usaha dan pelayanan pembiayaan dengan akad murabahah kepada nasabah. Namun, sejak tahun 2015 Bank Muamalat Cabang Utama Kota Malang sudah tidak lagi menjalankan perjanjian pembiayaan dengan akad murabahah dikarenakan mereka menganggap bahwa fakta di lapangan tidak memenuhi ketentuan atau tidak sesuai lagi dengan prinsip akad murabahah yang seharusnya. Ketidaksesuaian ini sering kali terjadi pada pembiayaan KPR IB Muamalat atau pembiayaan pembelian rumah KPR.

Pada ilustrasi yang sudah penulis paparkan di atas dapat dilihat bahwa nasabah memang dapat mendatangi pihak bank syariah terlebih dahulu atau datang ke supplier atau developer dahulu, sesuai dengan salah satu syarat yang harus terpenuhi dalam prinsip transaksi akad pembiayaan murabahah bahwa kedua belah pihak harus mengetahui harga pertama (harga pembelian) karena merupakan syarat sahnya transaksi jual beli. Adapun di dalam praktek yang terjadi di perbankan syariah dan menjadi permasalahan tidak terpenuhinya prinsip akad murabahah adalah nasabah mendatangi pihak supplier atau developer dahulu, melakukan negosiasi harga sampai pada membayar uang muka dari harga yang ditawarkan kepada pihak supplier atau developer baru kemudian mendatangi Bank Muamalat untuk mengajukan permohonan pembiayaan dengan akad murabahah, akan tetapi harga yang disampaikan bukan harga yang sebenarnya namun harga yang sudah dipotong uang muka.

Transaksi yang dilakukan antara pihak Bank Muamalat dengan supplier atau developer merupakan transaksi pertama, kemudian transaksi Bank Mumamalat dengan nasabah merupakan transaksi kedua sehingga peran nasabah adalah sebagai pembeli kedua. Jika transaksi pertama tidak sah atau bahkan tidak pernah terjadi, maka tidak boleh dilakukan perjanjian pembiayaan secara akad murabahah karena kembali pada definisi akad murabahah itu sendiri yang merupakan jual beli dengan harga awalyang ditambah dengan margin keuntungan dan kepemilikan harus berada pada bank berlabel syariah secara prinsip.

Berdasarkan hal tersebut dapat dilihat bahwa terjadi ketidakjujuran yang dilakukan nasabah, di mana seharusnya nasabah memberitahukan harga asli dari barang yang diinginkan dan akan menjadi objek dari perjanjian serta membayar uang muka kepada pihak Bank Muamalat bukan dengan supplier atau developer. Karena prinsip dari pembiayaan akad murabahah bahwa Bank Syariah dalam hal ini bank Muamalat yang akan bertindak sebagai pembeli dari developer karena barang yang menjadi objek perjanjian harus benar-benar dimiliki oleh Bank Muamalat terlebih dahulu 
lalu kemudian dijual kepada nasabah berdasarkan kesepakatan-kesepakatan yang telah dibuat.

Alasan-alasan tersebut membuat Bank Muamalat pada akhirnya menghentikan pembiayaan dengan akad murabahah karena sangat memegang teguh prinsip syariah. Seperti yang diketahui secara umum bahwa Bank Muamalat adalah bank syariah pertama yang berdiri di Indonesia, untuk itu mereka tidak ingin label bank "syariah" yang melekat pada mereka hanya sekedar wacana dan menjaganya dengan sungguhsungguh.

Meskipun pembiayaan dengan akad murabahah dihentikan oleh Bank Muamalat akan tetapi mereka memberikan pelayanan pembiayaan lainnya dengan akad musyarakah mutanaqisah. Musyarakah Mutanaqisah merupakan produk pengembangan dari produk dengan akad musyarakah. Musyarakah Mutanaqisahdijalankan dengan prinsip syirkah 'inan ${ }^{6}$ sebagai produk pembiayaan perbankan syariah. Syirkah Inan adalah akad kerja sama usaha antara bank dengan debitur/nasabah, di mana mereka akan memberikan uang sebagai modal dengan bagian modal yang berbedadi mana pada umumnya porsi modal salah satu pihak dalam hal ini bank menjadi berkurang disebabkan oleh pembelian atau pengalihan komersial secara berangsur kepada mitra lain yaitu nasabah.

\section{Faktor Pendukung dan Penghambat}

Hadirnya perbankan syariah di Indonesia memang menjadi salah satu solusi dalam perkembangan ekonomi masyarakat Indonesia, menjawab kegelisahan masyarakat yang tidak ingin terlibat dalam bunga/riba pada bank konvensional. Perkembangannya yang pesat salah satu faktornya karena ada dukungan positif dari pemerintah seperti DSN MUI. Namun demikian, masih belum ada ketentuan khusus syariah yang benar-benar mengatur perbankan syariah di Indoneisa. Sehingga, tentu saja dalam perkembangannya dari awal berdiri hingga menjalankan segala kegiatan dan mengeluarkan produk-produk yang berbasis syariah terdapat banyak faktor yang di sisi lain sebagai pendukung akan kemajuannya, di sisi lain sebagai penghambat dan perlu evaluasi-evaluasi untuk mencari solusi dan strategi baru dalam mengatasi faktor penghambat tersebut.

Adapun berikut ini merupakan beberapa faktor-faktor pendukung dan penghambat bagi perbankan syariah pada umumnya dan khususnya bagi bank Muamalat dalam melaksanakan kegiatan usaha serta mengeluarkan produk-produk mereka yang berbasis syariah.

1. Faktor Pendukung

${ }^{6}$ Ismail, Perbankan Syariah, (Jakarta: Kencana, 2011), hal, 184 
Beberapa alasan pendukung transaksi murabahah mendominasi minat nasabah dalam pembiayaan di bank syariah adalah :

a. Akad pembiayaan murabahah mudah diimplentasikan juga dimengerti oleh masyarakat karena beberapa bank syariah masih menganggap bahwa ketentuan akad murabahah sama dengan ketentuan perjanjian kredit pada bank konvensional. Terlebih dalam hal pembiayaan seperti kendaraan bermotor, kepemilikan rumah dan kredit lainnya. Meski pada hakikatnya ada hal yang secara prinsip membedakan kedua transaksi tersebut yakni perihal akad atau kesepakatan yang digunakan. Hal ini disebabkan karena masih belum ada regulator yang mengatur secara khusus mengenai ketentuan bank syariah, sehingga masih ada beberapa bank syariah yang masih menjalankan transaksi murabahah dengan proses yang hampir sama dengan kredit pada bank konvensional.

b. Penghasilan bank sudah bisa diketahui sejak awal.Hal ini dikarenakan hal yang menjadi objek perjanjian adalah harga jual, karena pada harga jual sudah termasuk harga pokok ditambah dengan laba.

c. Pada transaksi akad murabahah, hubungan bank dan debitur adalah hubungan hutang piutang, jadi debitur harus membayar hutang harga barang yang diperjualbelikan sebagai kewajibannya pada bank.

d. Menyamakan murabahah dengan pembiayaan konsumtif. Jika dilihat secara seksama, seolah terdapat persamaan antara jual beli dengan pembiayaan konsumtif. Akan tetapi sesungguhnya terdapat perbedaan yang cukup mencolok karena ketentuan fatwa yang mengatur juga berbeda. Contohnya, debitur yang mengajukan permohonan untuk dibiayai pembelian komoditi atau barang sekunder. Dalam hal ini debitur dapat membayar kepada bank secara angsuran dengan jangka waktu yang disepakati maupun membayar dengan lunas, membayar diawal atau membayar secara bertahap seperti halnya untuk pembangunan rumah. Inti persamaan dari cara pembayaran tersebut adalah peralihan hak milik baru akan terjadi jika debitur sudah melakukan pelunasan.

2. Faktor Penghambat

Hal-hal yang harus diantisipasi di antaranya adalah sebagai berikut:

a. Nasabah melakukan dengan sengaja lalai dalam membayar kewajibannya;

b. Fluktuatif harga, hal ini bisa terjadi bila harga suatu barang di pasar mengalami kenaikan setelah bank membelikan barang tersebut untuk nasabah. Sehingga bank tidak dapat mengubah harga jual beli tersebut.

c. Adanya penolakan dari debitur disebabkan barang rusak dalam perjalanan, karena itu sebaiknya dilindungi dengan asuransi, kemungkinan lain karena debitur merasa spesifikasi barang tersebut 
berbeda dengan yang ia pesan, bila bank telah menandatangani kontrak pembelian dengan penjualnya, barang tersebut akan menjadi milik bank, dengan demikian bank memiliki resiko untuk menjualnya kepada pihak lain.

d. Debitur menjual barang sebelum pelunasan, karena merasa bahwa setelah perjanjian pembiayaan akad murabahah ditandatangani, barang itu menajdi miliknya sepenuhnya, sehingga debitur bebas melakukan apapun terhadap aset tersebut, termasuk untuk menjualnya, hal ini dapat menyebabkan resiko yang cukup besar karena kelalaian membayar dari debitur.

Pada Bank Muamalat Kota Malang hal-hal yang menjadi faktor penghambat adalah tidak dapat diterapkannya pembiayaan dengan akad murabahah karena dirasa kurang pas dan tidak sesuai dengan prinsip akad murabahah dan prinsip syariat Islam. Juga karena mereka sangat menyadari betul bahwa belum ada regulator khusus yang mengatur tentang perbankan syariah, regulator yang ada masih menggunakan ketentuan hampir sama dengan bank konvensional. Sehingga mereka tidak ingin kata "syariah yang melekat pada Bank Muamalat hanya sekedar labelling saja. Mereka ingin menjaga dan berpegang teguh pada prinsip syariah berdasarkan hukum Islam.

Dadan Muttaqien dan Fakhruddin Cikman memaparkan tentang resiko tertentu yang akan dialami bank syariah saat melaksanakan pembiayaan murabahah sebagaimana berikut:

a. Resiko Pembiayaan, yaitu resiko yang tidak bisa diprediksi oleh bank dan dapat terjadi karena nasabah gagal atau sudah tidak dapat melakukan pembayaran atau pelunasan kembali pembiayaan murabahah;

b. Resiko pasar, yaitu resiko yang terjadi disebabkan oleh terjadinya perubahanpersentase bunga di pasar yang dapat berpengaruh besar pada hitungan pembagian laba, karena laba sudah ditentukan pada awal perjanjian sesuai kesepakatan antara bank dengan debitur dan tidak diperkenankan untuk berubah selama perjanjian berjalan;

c. Resiko strategi, terjadinya disebabkan oleh kekeliruan perhitungan bisnis dari bank saat menyetujui pembiayaan kepada debitur;

d. Resiko hukum, hal ini disebabkan oleh masih belum ada regulator yang diberlakukan untuk mengatur terkait bank syariah secara khusus sehingga dalam menjalankan kegiatan usahanya bank syariah masih berpedoman pada regulasi hukum yang ditetapkan bagi bank konvensional. ${ }^{7}$

${ }^{7}$ Dadan Muttaqien Dan Fakhruddin Cikman, Penyelesaian Sengketa Perbankan Syariah, Ctk. Pertama, (Yogyakarta: Total Media, 2008), hal. 5, dan Bagya Agung 


\section{KESIMPULAN}

Penerapan akad pembiayaan murabahah di bank Muamalat Kota Malang telah berusaha mengikuti ketentuan sebagaimana fatwa yang dikeluarkan Fatwa DSN MUI tentang akad murabahah. Hanya saja dalam penerapannya di lapangan terdapat perbedaan bahkan tidak memenuhi prinsip akad murabahah yang seharusnya. Hal yang harus dipenuhi dalam akad pembiayaan murabahah bahwa kedua belah pihak harus mengetahui harga pertama (harga pembelian) karena merupakan syarat sahnya transaksi jual beli. Pihak bank Muamalat merupakan pembeli pertama dari supplier atau developer yang nantinya menajdi penjual bagi nasabah yang merupakan pembeli kedua, sehingga dapat dilihat bahwa terdapat dua transaksi yang harus dilewati. Jika transaksi pertama tidak sah atau bahkan tidak pernah terjadi karena nasabah langsung mendatangi pihak supplier atau developer sekaligus membayar uang muka kepada mereka bukan kepada bank Muamalat. Hal-hal tersebut yang menyebabkan tidak terpenuhinya prinsip akad murabahah dan membuat Bank Muamalat kantor cabang utama Kota Malang menghentikan pembiayaan akad murabahah.

Sebagai solusinya mereka mengeluarkan produk pelayanan pembiayaan dengan akad musyarakah mutanaqisah. Musyarakah mutanaqisah adalah perjanjian kerjasama mitra dengan masing-masing menyerahkan modal dengan nominal yang tidak harus sama di mana nantinya porsi salah satu pihak yaitu bank menjadi berkurang karena pembelian atau pengalihan komersial kepada nasabah dan dibayar secara angsuran.

\section{DAFTAR PUSTAKA}

\section{Buku}

Ahmad Ifham Sholihin, 2010, Buku Pintar Ekonomi Syariah, Jakarta: Gramedia Pustaka

Bagya Agung Prabowo, 2012, Aspek Hukum Pembiayaan Murabahah Pada Perbankan Syariah, Yogyakarta: UII Press

Dadan Muttaqien Dan Fakhruddin Cikman, 2008, Penyelesaian Sengketa Perbankan Syariah, Ctk. Pertama, Yogyakarta: Total Media

Ismail MBA, 2011, Perbankan Syariah, Jakarta: Kencana

Jonaedi Efendi dan Johnny Ibrahim, 2018, Metode Penelitian Hukum Normatif dan Empiris, Depok: Prenadamedia Group.

Prabowo, Aspek Hukum Pembiayaan Murabahah Pada Perbankan Syariah, (Yogyakarta : UII Press, 2012), hal. 34 


\section{Peraturan Perundang-undangan}

Undang-Undang Nomor 7 Tahun 1992 tentang Perbankan

Undang-Undang No. 10 Tahun 1998 tentang Perubahan Undang-Undang Nomor 7 Tahun 1992 tentang Perbankan

\section{Internet}

Cecep Supriadi, 2014, Bagaimana Masa Depan Retail Banking di Indonesia? diakses dari https://marketing.co.id/ pada 24 Juli 2019

Kamus Bisnis dan Bank diakses di http://www.mediabpr.com/ pada 24 Juli 2019 